\title{
Tyrkiets religiøse dilemma
}

\section{Martin Selsøe Sørensen}

\section{På den ene side er islam en fundamental del af det at være tyrkisk og et vigtigt bånd til nationerne i Mellemøsten. På den anden side er det en hæm- sko i forholdet til Europa}

Den tyrkiske regering har påtaget sig en maleopgave, der kræver et vanvittigt raffineret talent. Når man kigger fra Europa skal billedet af det nye Tyrkiet fremhæve landets verdslige demokrati og nedtone religion, som Tyrkiet ikke ønsker skal spille nogen rolle i landets optagelsesforhandlinger med EU. Men når man kigger på billedet fra Mellemøsten er det omvendt et plus, at man ud over det verdslige demokrati også ser landets islamiske karakter. Eller sagt på en anden måde: Folk i Mellemøsten huskes på, at islam er en betydelig del af den tyrkiske nation, mens folk i Europa gøres opmærksomme på, at det ikke betyder så meget endda.

At tegne to så forskellige billeder på samme tid er i sagens natur ikke let, og øvelsen bliver ikke lettere af, at den tyrkiske regeringschef gerne så sig ophøjet til talsmand for alverdens muslimer, og en gang i mellem lever den ønskerolle ud. Samtidig viser Tyrkiets forsøg på at skabe sig en ny rolle og et nyt image, at der er behov for, at Vesten forstår hvad Tyrkiets rolle skal være, og hvorfor landet er så velegnet til at spille den.

Siden den moderne tyrkiske republik blev grundlagt i 1923, har religion været under skarp kontrol af den tyrkiske stat. Har man forstået det sådan, at religionen er blevet holdt ude, har man misforstået noget: Religionen har fået lov at eksistere, men kun i et lukket rum, hvor staten har kunnet kontrollere den. Spørgsmålet har derfor ikke været, om islam kunne rumme demokrati, men om demokratiet kunne rumme islam.

Som instrument i statens hænder har islam blandt andet været brugt til at konstruere tyrkisk identitet, som ud over sunni-islam også bygger på det tyrkiske sprog og tyrkisk nationalitet. Alle borgere i Tyrkiet, der 


\section{TEMA: RELIGION I INTERNATIONAL POLITIK}

ikke både er sunnimuslimer, taler tyrkisk og har tyrkisk nationalitet opfattes ikke som rigtige tyrkere i flertallets øjne, og det er gået ud over for eksempel kristne og kurdere.

De seneste fire år har set en række henrettelser af fremtrædende kristne tyrkere flere steder i landet, men alle de drab er begået af nationalister og ikke religiøse ekstremister. Nationalisterne mener, at kristne udgør en trussel mod islam og dermed mod Tyrkiet, og det er der derfor, de blevet slået ihjel. Ikke fordi de opleves som en trussel mod islam i sig selv.

Statens insisteren på at definere religion har betydet, at de religiøse, der gerne selv vil bestemme troens udfoldelse, ligesom kristne og kurdere, har været fortrængt til periferien af det tyrkiske samfund helt frem til midten af $1990^{\circ}$ erne.

På det tidspunkt vandt religiøse politikere, og med dem Recep Tayyip Erdogan, borgmesterposter flere steder i Tyrkiet og banede dermed vejen mod centrum af samfundet og den første religiøse regering i Tyrkiet i 1997 og den næste i 2002.

At Tyrkiets militær ni år senere så småt har lært at leve med en religiøs regering, siger både noget om islams karakter i Tyrkiet og graden af demokratiets rodfæstethed i samfundet. Kun de færreste tror for alvor, at Erdogan er en tyrkisk Ayatollah Khomeini, og under alle omstændigheder er det klart, at de tyrkiske vælgere ikke har stemt på ham med den forventning og helt sikkert vil løbe skrigende væk, hvis han skulle afsløre den slags ambitioner. Det betyder ikke, at han ikke vil noget på religionens vegne, det betyder bare, at tro ikke er den drivende kraft bag hans politik.

Det har været småt med konkrete fremskridt for religionsudfoldelsen under Erdogan, fordi det politiske klima ikke har været til det. Men det er klart, at ministerpræsidenten gerne så, at hans vælgere kunne få lov at definere religionen, som de selv vil. Det vil sige få ret til at bære hovedtørklæder på universiteter og offentlige institutioner og hvem ved: Give menighederne lov til at ansætte deres egne imamer. I dag må de leve med dem staten gennem Diyanet, ministeriet for religiøse anliggender, ansætter og sender ud til tyrkiske menigheder over hele verden.

\section{Ledestjerne i Mellemøsten}

Relationen mellem stat og religion og graden af demokrati gør Tyrkiet indlysende relevant som ledestjerne for de befolkninger i Mellemøsten, der i disse måneder er på vej ud af årtiers formørket diktatur.

Regeringen i Ankara gør sig store anstrengelser for ikke at trænge sit forbillede for meget på, da demokrati og politisk reform ikke er elementer i landets udenrigspolitik. Men den ser gerne regionen omskabt i sit billede, fordi Tyrkiet vil nyde godt af en region i fred og 
fremgang, og fordi det vil stive landet af i rollen som den stærkeste magt i regionen. Tunesiens hjemvendte Rachid Ghannouchi fra det indtil videre forbudte islamistiske parti al-Nahda har flere gange givet udtryk for, at Tyrkiet er modellen, han gerne ser det nye Tunesien formet efter. Sit eget parti vil han hellere end noget andet religiøst parti sammenligne med Erdogans Adalet ve Kalkinma Partisi (Retfærdighedsog Udviklingspartiet, AKP).

For den tyrkiske ministerpræsident er det noget, der luner. Det han særligt ser, når han kigger ud over Mellemøstens forhutlede oppositionsfigurer, er nemlig en reflektion af sig selv og sin historie. Fra Hamas i Palæstina, til Det Muslimske Broderskab i Egypten og alNahda i Tunesien er der tale om religiøse bevægelser, der uanset deres budskab i øvrigt er blevet bortskammet og foragtet, fordi de er religiøse. Samme skæbne led han i 1997 , da han reciterede et religiøst digt og blev straffet med fængsel og forbud mod deltagelse i politik i fem år.

I skrivende stund ser revolutionerne i Mellemøsten ud til at være alt andet end islamiske. Ingen steder har kampråbene været religiøse, men derimod for verdslige dyder som retfærdighed, respekt og retten til selvbestemmelse. Hvis Mellemøstens religiøse bevægelser vil tiltrække vælgere, er det med den slags paroler det skal ske og ikke med religiøse paroler. Præcis samme opskrift som Erdogan og AKP har fulgt.

En ting bekymrer Tyrkiets vestlige partnere. Tyrkiet har hurtigt og hårdt fordømt Israels angreb på palæstinenserne og USA's invasion af Irak, men om for eksempel Iran og Sudan, hvor muslimer slås ihjel af andre muslimer, har Ankara ikke sagt en lyd. Tværtimod har Erdogan forklaret sit nære forhold til Sudan præsident Omar al-Bashir med, at "muslimer kan ikke begå folkemord".

\section{Vestlig bekymring}

Det har undret og bekymret i Vesten, at der tilsyneladende var en blindhed over for for menneskerettighedskrænkelser begået af muslimer. Det har revolutionerne i Mellemøsten imidlertid leveret en afklaring på, for så snart det stod klart, at Hosni Mubarak uigenkaldeligt var på vej ud, tonede Tyrkiet rent flag og fordømte ham. Den tidligere tøven var tilsyneladende blot påpasselighed af hensyn til Tyrkiets økonomiske interesser og politiske indflydelse i Egypten. Ikke så kønt, men meget pragmatisk.

I forholdet til Europa er det åbenbart, at religion har domineret bedømmelsen af landets optagelsesmuligheder i hvert fald de senere år. Samtidig med Grækenland fik Tyrkiet i 1979 tilbudt medlemskab uagtet dets muslimske flertal, så det er rimeligt at antage, at forbeholdet over 
for religion er af nyere dato begyndende fra Murens fald og forstærket af 11. september 2001 og valget af det religiøse AKP i 2002. Siden da er statsledere i først og fremmest Tyskland, Frankrig og Østrig for alvor begyndt at bekymre sig om det potentielle medlemsland, dets religion og hvad et medlemskab måtte få af betydning for Unionen.

Skiftet i europæernes syn på Tyrkiet er paradoksalt nok kommet i samme periode, som nationen er gået fra at være en fattig landbefolkning styret af generaler til at være et indflydelsesrigt og uafhængigt demokrati med en hastigt voksende økonomi. Det er et besynderligt signal at sende til demokratiaspiranterne langs den sydlige del af Middelhavet.

\section{Med 1, 5 mia. på skuldrene}

Man kan kalde det unfair af EU-landene at blande religion ind i optagelsesproceduren til en klub, der formelt ingen religiøs dimension har. Tilsvarende kan man kalde det utilgiveligt, at Tyrkiet ikke for længe siden har taget den udfordring alvorligt og er begyndt at påvirke opinionen i Europa, og ikke mindst i de tre mest Tyrkiet-kritiske lande.

I stedet for at gå offensivt til udfordringen har Tyrkiet skiftevis været fornærmet over enhver antydning af, at religion spiller en rolle, skiftevis været i byen som ambassadør for ikke bare Tyrkiets kandida- tur, men for religiøse følelser i hele den muslimske verden mellem Marokko og Indonesien.

Hør Tyrkiets minister for EU-forhandlinger i et interview med nyhedsbureauet Reuters i 2009:

"Desværre skaber det grundløs mistænksomhed, at de fleste tyrkere er muslimer. Folk har det med at frygte det, de ikke kender", sagde Egemen Bagis, og tilføjede: "Ved hvert møde jeg har med mine europæiske partnere føler jeg presset fra (...) 1,5 milliarder mennesker på mine skuldre".

Da NATO skulle vælge generalsekretær samme år, og talen faldt på Anders Fogh Rasmussen, førte Erdogan telefonsamtaler med arabiske ledere og meddelte NATO-kredsen, at hans kontakter stadig var vrede på danskeren. Forsøget på at bringe sagen om Jyllands-Postens Muhammedtegninger med til bords i NATO faldt mildt sagt i dårlig jord hos Tyrkiets partnere, og Erdogan skiftede undervejs position og hængte i stedet sit ubehag op på den danske sendetilladelse til tv-stationen Roj-tv. Tyrkiet ønsker stationen lukket på grund af påståede forbindelser til de kurdiske oprørere i det forbudte PKK.

Brugen af religion i den politiske debat og Vestens overfølsomme reaktion har siden fået Tyrkiet til at nedtone religiøse følelser som argument. I stedet handler argumenterne for tyrkisk optagelse om økonomi og udenrigspolitik, hvor Tyrkiets 
bidrag er helt anderledes konkret og umiddelbart anvendeligt. "For hver dag der går, har Tyrkiet mindre brug for EU og EU mere brug for Tyrkiet", er Egemen Bagis' nye primære talepunkt, når han skal argumentere for Tyrkiet i Europa. Det budskab er ikke helt sunket ind i Europa, men i det mindste giver det ingen profylaktiske chok.

Tilbage står, at Tyrkiet stadig ikke for alvor har fået forklaret europæerne, hvem de er og hvad landet har at tilbyde. For få vælgere i Europa kender til Anatoliens superdynamiske byer og avancerede industri endsige Istanbuls natteliv. Et rigt natteliv er ganske vist ikke et af EU's Københavnerkriterier, som kandidatlande skal leve op til for at komme i betragtning, men et bredere og dybere kendskab til Tyrkiets mangfoldighed vil afmystificere landet.

I dag er kendskabet ofte domineret af det image, der efterlades af gadebilledernes mænd med blå strikhuer, der for 30 år siden flyttede til Europa for at arbejde, og deres hustruer med brune tørklæder og frakker. Eller diverse discountdestinationer på den tyrkiske Middelhavskyst. Begge er de elementer i det moderne Tyrkiet, men landet skylder sig selv at præsentere nogle af alle de andre, så det bliver klart, at Tyrkiet kulturelt og socialt ikke er så fremmedartet endda. I hvert ikke hvis man i stedet for at sammenligne med Danmark, sammenligner Tyrkiet med Middelhavslandene.

\section{Religion nedtones}

Tyrkiet har, i hvert fald for en stund, nedtonet religion i debatten med $\mathrm{EU}$, men alligevel er religion fortsat højt på dagsordenen i landets omgang med dets naboer. Tydeligst på Balkan hvor Tyrkiets ministerium for religiøse anliggender, Diyanet, har kastet sig ind i kampen om muslimske sjæle. Både saudiarabiske og sudanesiske organisationer har tidligere forsøgt at sætte sig på islamisk uddannelse i Albanien og Bosnien, men kun Tyrkiet har for alvor haft held og tilstrækkelig fingerspidsfornemmelse til det.

I 1990'ernes Albanien, før Tyrkiet for alvor fik øjnene op for sit nabolag, var Saudi-Arabien den primære sponsor for religiøse albaneres uddannelse med en udpræget salafistisk tendens i Albanien til følge. Salafister opfatter sig selv som dyrkere af den reneste form for islam, mens mange andre opfatter dem som ekstremister i al-Qaeda-klassen.

Siden er kommet hundreder af stipendier til unges studier i Tyrkiet, private tyrkiske skoler og organisationer med religiøst islæt, og Diyanet har kørt sig ind som både rådgiver for albanske religiøse institutioner og som arrangør af albanske muslimers pilgrimsrejser til Mekka. Det samme gør ministeriet for tyrkiske muslimer fra hele verden.

"Slaget i det muslimske samfund har altid stået mellem en pro-arabisk fraktion og en pro-tyrkisk. Det 
ser nu ud til, at den tyrkiske fraktion er ved at vinde afgørende", siger Pirro Misha, en albansk intellektuel, til Balkan Fellowship for Journalistic Excellence. Det er klart, at de muslimske lande, der opstod efter det osmanniske riges sammenbrud, alle har en særlig opfattelse af Tyrkiet som centrum for både tanke og tro, og derfor finder det nærliggende fortsat eller igen at kigge dertil efter inspiration og lederskab.

\section{Tiltrækker på Balkan}

For EU betyder det, at landene på Balkan ser en stadig stærkere attraktion i Tyrkiet, der som tiden går bliver bedre og bedre i stand til at matche EU i forhold til for eksempel økonomisk vækst. Kulturelt og historisk ligger Tyrkiet også tættere på området end Nord- og Vesteuropa.

Konkurrencen med EU er ganske reel, for Tyrkiets indflydelse på Balkan er ikke begrænset til de muslimske lande. Sidste år lykkedes det Tyrkiet at mægle en aftale mellem Serbien og Bosnien, der betød, at Serbien tog ansvar for massakren i Srebrenica, og de to lande for første gang siden krigen kunne udveksle ambassadører. Tyrkiet mægler også mellem Serbien og Kroatien og har øjne på konflikten mellem Serbien og Kosovo.

For regeringen i Ankara har det været svært at finde en balance mellem at spille på båndene til alverdens andre muslimer og forholdet til Europa, der tydeligvis ikke tåler Tyrkiets muslimske identitet. På den ene side har regeringen skamløst brugt religion i promoveringen af lidelserne for palæstinenserne i Gaza og igen ved valget af Anders Fogh Rasmussen i NATO. På den anden side er det ikke i Tyrkiets interesse at blive set i Europa som den muslimske nation, fordi islam uafladeligt får europæere til at se alt, hvad de gør og mener, i det lys.

Tyrkiet hverken kan eller vil se bort fra, at det er en muslimsk nation og derfor har nogle særlige bånd til andre muslimske lande. Men det er også en tidligere imperienation, og det er i virkeligheden derigennem Tyrkiets betydning er størst. Det nationerne i Mellemøsten og på Balkan ser i Tyrkiet er ikke blot en muslimsk nation, men en der frem til efter Anden Verdenskrig var deres lige økonomisk og socialt. I dag er Tyrkiet vokset økonomisk, socialt og politisk, og så har tyrkiske investorer både penge og knap så mange kvababbelser over nye, lidt usikre markeder som deres europæiske konkurrenter.

Det er det, det store billede med alle facetterne, kristne nationer som Serbien og også Georgien først og fremmest ser, når de kigger mod Tyrkiet. Det er muslimsk, javist, men også så meget andet.

Martin Selsøe Sørensen er Politikens korrespondent $i$ Tyrkiet og medlem af Udenrigs' redaktionskomite. 